\title{
Impact of Treated Wastewater on Some Physicochemical Parameters Soil and Its Fungal Content
}

\author{
Abdulmajeed Mlitan, Abdullah Abofalga, and Abdelaziz Swalem
}

\begin{abstract}
This study was carried out to investigate the effect of treated wastewater on soil chemical and physical properties. Field experiment was conducted in Misurata region in central Libya with water treatments of wastewater. The Soil physicochemical parameters such as, $\mathrm{pH}$, water content, total soluble salts, Cadmium, Zinc, Lead, Cupper and Iron of soil added treated industrial west water. The results reveal that the some sampling sites were affected by industrial west water pollution. Soil water content ranged from 7.68 to 19.56 . $\%$. Total soluble salts ranged from 272.6 to $300 \mathrm{ppm}$ and soil $\mathrm{pH}$ ranged from 7.7 to 8.0 . and showed no appreciable differences within localities. The all tested metals increased from first location to the third location except Iron. The irrigation system had a significant effect on Total soluble salts and microbial flora. Isolated microbial flora consists of 4 fungal genera belonging to, Aspergillus, Penicillium, Rizopus and Fusarium. The latter and one of the Aspergillus spices (Aspergillus $\mathbf{~ s p}_{3}$ ) may consider one of the resistance fungi to industrial west water due to its large colonies numbers isolated from water contaminated metals area.
\end{abstract}

Index Terms-Soil quality, physicochemical parameters, west water interstitial.

\section{INTRODUCTION.}

The presence of heavy metals and residues from rod and town houses and industrial wastes has been found to be the causes of pollution in soil. wastewater possesses different biological, physical and chemical effects on the environment. Some physicochemical analysis of soil affected by industrial pollution significantly needed [1]. Microorganisms and human being received pollutants which is toxic when any kind of pollution come in and accumulating into the soil [2]. Nearly $90 \%$ of $\mathrm{Cd}, \mathrm{Ni}$, and $\mathrm{Pb}$ accumulated in the $10-15 \mathrm{~cm}$ soil depth when this soil irrigated with wastewater [3]. Although many of elements including heavy metals are required by living organisms for their normal function [4], these elements considered one of the most harmful industrial pollutants in the environment also at high concentrations, they become toxic. Its known that in environment, metals including heavy metals can be present as either dissolved elements or as suspended elements. These heavy metals can affect soil and its content including micoorganismes particularly fungi. Although, some fungi mentioned as heavy metals tolerant [4]. The presence of pollution-tolerant species is often used as an indicator of pollution resulting from industrial discharge in aquatic systems [4]-[6]. Several

Manuscript received June 18, 2014; revised August 11, 2014.

Abdulmajeed Mlitan is with the Department of Botany, College of Science, Misurata University, Misurata, Libya (e-mail: aefmsr2012@yahoo.com). investigations have been carried out to study the effect of treated wastewater on soil chemical and physical properties [7]-[9]. Monitoring the contamination of soil by different kinds of pollutants is of great importance because of their potential effects on arable land and groundwater. An example of such a pollutant is factories dust, which can affect the chemical properties of soil. The physico-chemical properties of soil contaminated by metals were changed which made the soil unsuitable for plant growth. Clay minerals, organic matter, $\mathrm{pH}$, temperature, redox potential and interrelationships between heavy metals themselves are the physicochemical factors which can affect the interactions between soil microorganisms and heavy metals. In addition, wastewater possesses different biological, physical and chemical effects on the environment. Several forms of nitrogen is present in wastewater, for example as ammonia $\left(\mathrm{NH}_{3}\right)$, ammonium $\left(\mathrm{NH}_{4}{ }^{+}\right)$, nitrate $\left(\mathrm{NO}_{3}{ }^{-}\right)$, nitrite $\left(\mathrm{NO}_{2}{ }^{-}\right)$and as organic compounds. Wastewater without treatment may has nitrogen and is mostly present in the form of $\mathrm{NH}_{4}$. Nitrogen is an essential nutrient for biological growth. It is one of the main components in all living organisms such as plants and microorganisms such as fungi.

With increasing evidence of the adverse effects of pollutants on soil, air, water and their populations, these environments have received much attention in recent years [2]-[4]. Changes in soil properties have been associated with environmental alteration that takes place, for example as a result of human activity. As soon as any kind of pollution contacts the soil surface its constituents enter inside the earth. Its metal constituents undergo several reactions which can affect soil including its chemical and physical characteristics. As wastewater may have a high metals or salts content, this tends to be highly alkaline. Therefore, it is likely that soil contaminated by wastewater may have high $\mathrm{pH}$. In order to apply the wastewater for irrigation it should obtain the certain criteria of qualification after treatment, for parameters such as electrical conductivity (EC), total dissolved solids (TDS), and sodium adsorption ratio (SAR). Suspended materials and organic matters are also other parameters, which might be considered before application of wastewater to agricultural lands. The principal processes which affect the physical properties of the soil by using the wastewater are the salt contents and the suspended solids. A large number of studies have investigated fungi isolated from acidic to neutral soils. However, relatively few have investigated fungi in alkaline soils. Soils with high concentrations of metals, salts or exposed to factories dust were studied by many presenters. In these studies the most common fungi were Aspergillus, Cladosporium, Gliocladium, Mucor, Penicillium, Trichoderma, Acremonium species and two Chrysosporium species. Almost of these fungi grew well in alkaline 
conditions. In addition, several fungi such as Emericellopsis minima, Melanospora zamiae, Neosartorya stramenia and Neurospora tetrasperma isolated from alkaline soils were studied.

The relationships among soil properties, fungi, and wastewater as a pollutant have been explored in relatively few studies. Those studies did not focus on the effects of wastewater on fungal characteristics such as protein or enzyme content or pigmentation products, nor did they present a particular reason why such effects occur.

\section{Aims}

No published reports have examined the occurrence of fungi in soils irrigation by wastewater in Libya. To our knowledge, no previous studies have investigated fungal flora and Soil physicochemical parameters in soils irrigated with wastewater and this study should be the first work in Libya.

Therefore, this paper aims to investigate the effect on soil irrigation by wastewater in Libya. Genera of fungi which are present in soil irrigation by wastewater were investigated, as well as the present study was carried out to determine the soil content of heavy metals, water content, $\mathrm{pH}$ and total soluble salts in soil Irrigation by treated industrial wastewater Misurata station, comparing the findings with those for soil samples taken from an unpolluted area (non irrigation by wastewater).

\section{MAterials AND Methods}

\section{A. Outline of the Treated Wastewater Misurata Station and Surrounding Area}

The field research area lies near the coast of Libya at latitude $32.65 \mathrm{~N}$ (north) and longitude 14.26 E (east). The station is located about $100 \mathrm{~km}$ east of Tripoli (Libya's capital city). Misurata wastewater treatment station is one of several government wastewater treatment stations in Libya. It was built in 1989. It produces about 24,000-72,000 $\mathrm{m}^{3}$ daily. Cultivated soils adjacent to the Misurata wastewater treatment station have been Irrigationed by wastewater. However, the area holds benefits for farming barley (Hordeum vulgare), Medicago sativa, Medical Herbs and vegetable growing. Also, a number of trees grow in the area such as palm trees. In the summer, the main direction of the wind is from the desert (south) to the sea (North). However, in the winter the wind blows from west to east. Generally speaking, the climate of the area in the summer is hot and dry. The temperature rapidly increases in this season, reaching $48^{\circ} \mathrm{C}$. In the winter it is warm and rainy but rainfall is scanty. In Libya, more than $50 \%$ probability of occurrence of $10 \mathrm{~mm}$ rainfall amounts can be noted in sixteen meteorological stations including the Misurata study area and rainfall of 25 to $50 \mathrm{~mm}$ can occur. 26 millimetres is the average annual rainfall for the country. The highest annual rainfall levels in the country occur in only two areas and the study area does not include these areas.

\section{B. Soil Samples}

Soil samples were collected from the soil surface Irrigation by treated wastewater of factors, hoses and streets (Misurata-
Libya) during spring 2011. In each case, the soil was scraped (1-10 cm depth) into a sterilized plastic bag using a stainless steel spoon. A total of three pooled samples were collected from four different locations in the area. All mentioned experiments were taken place on soil samples not Irrigation to wastewater as comparison.

\section{Determination of $\mathrm{Al}, \mathrm{Cd}, \mathrm{Ca}, \mathrm{Cu}, \mathrm{Pb}, \mathrm{Fe}, \mathrm{Mn}$ and $\mathrm{Zn}$ Concentration in Soil}

The determination according to the method described by [10] was done with the collected soil samples and each sample was passed through a $2.0 \mathrm{~mm}$. mesh sieve and digested in concentrated nitric acid (Analytical Grade $\mathrm{BDH}, \mathrm{UK}$ ) to estimate total $\mathrm{Al}, \mathrm{Cd}, \mathrm{Ca}, \mathrm{Cu}, \mathrm{Pb}, \mathrm{Fe}, \mathrm{Mn}$ and Zn content. Lead, cadmium, iron, copper, manganese, zinc, manganese and aluminium were chosen as representative metals whose levels in the environment represent a reliable index of environmental pollution and have been measured in other work on environmental pollution of soil, water, air, and fungi.

Briefly, $0.5 \mathrm{~g}$ of air-dried soil from each soil specimen was placed in a $100 \mathrm{ml}$ beaker with $15 \mathrm{ml}$ concentrated nitric acid, covered with a watch glass and heated at $90 \mathrm{C}^{\circ}$ for 15 minutes. After digestion, the digest was made up to $50 \mathrm{ml}$ with deionized water and analyzed for iron contents using an atomic absorption spectrophotometer.

\section{Atomic Absorption Spectroscopy}

For atomic absorption spectroscopy, a Unicam Solar 929 atomic absorption spectrophotometer was used. Atomic absorption spectroscopy is probably the most widely used analytical method for metals in biological and environmental contexts and has been used for metal analysis in fungi .

\section{E. Anlaysis of Some Soil Physiochemical Characteristics}

The determination of soil total soluble salts, water content and $\mathrm{pH}$ value were done according to the method described by [11].

\section{1) Soil salts content}

$10 \mathrm{~g}$ of soil samples were added to $20 \mathrm{ml}$ water and mixed well then rinse the EC meter electrodes rinsed in the solution. Then a reading by immersing the electrode in the water above the settled soil as per manufacturer instructions. The electrodes are fully covered.

\section{2) Water content}

Soil moisture determination is of major significance, as moisture affects biological activity in the soil. The water content of a soil is expressed as a percent of the oven-dry mass of the sample. A common method is used in which a soil sample is dried at $80^{\circ} \mathrm{C}$ to a constant weight. The dry weight of the soil is used as the divisor in the calculation because it expresses the absolute quantity of soil present.

Empty glass Petri dishes were weighed and their weights recorded on a soil analysis data sheet. After this, $10 \mathrm{~g}$ of soil from each station (A, B and C) at each site was weighed. After the soil samples had been placed in the dishes, all the dishes were weighed and weights recorded in the wet weight column on the data sheet. All samples were placed in an oven at $80^{\circ} \mathrm{C}$ and dried for $24 \mathrm{~h}$ so that the weights became constant. The soil analysis data sheet was used to record the 
dry weight. At the end, a calculation was made to obtain the water content as a percentage.

\section{3) Calculation}

$$
\text { Water content }(\%)=\left(M_{w}-M_{d}\right) / M_{d} \times 100
$$

$M_{w}=$ Mass of wet soil sample

$M_{d}=$ Mass of dry soil sample

\section{4) Measurement $\mathrm{pH}$ value}

In view of the high concentrations of some heavy metals and other substances which could increase soil $\mathrm{pH}, \mathrm{pH}$ was measured. According to a wide convergence of methods for measuring $\mathrm{pH}$ in soil, 1:2 soil: water suspensions were prepared: $10 \mathrm{~g}$ of soil from each station (A, B and C) at each site was weighed into a $250-\mathrm{ml}$ flask and $20 \mathrm{ml}$ distilled water was added. The contents were shaken for a few minutes. The $\mathrm{pH}$ was measured with a Jenway $3310 \mathrm{pH}$ meter (Jenway Ltd, $\mathrm{UK})$. The $\mathrm{pH}$ meter was calibrated with buffer solutions at $\mathrm{pH} 4,7$ and 9.

\section{F. Isolation of Fungi from Soil}

Using the dilution plate method, Sabouraud medium and Czapek medium, total number of fungi per gram of soil for each type of soil samples was determined by method described by [12]. Soil suspensions were prepared by suspending $25 \mathrm{~g}$ of soil in water to a total volume of $250 \mathrm{ml}$. The soil suspension was transferred to a conical flask and mixed well with a magnetic stirrer. The suspension was diluted tenfold with distilled water. Rose bengal agar (Oxoid; $32 \mathrm{~g}$ in 1 litre distilled water) was prepared and autoclaved at $121^{\circ} \mathrm{C}$ for $15 \mathrm{~min}$. After this, the medium was poured out into petri plates and $2 \mathrm{ml}$ soil suspension was spread on each plate. Two plates were prepared from each station (A, B, and C) at each site (6 cultures from each site). All plates were incubated at $25^{\circ} \mathrm{C}$ and fungi were recorded after 10 days. The fungal colonies were subcultured onto fresh Czapek Dox agar to purify them for subsequent identification.

\section{G. Sabouraud Medium}

To prepare Sabouraud agar medium, $10 \mathrm{~g}$ bacteriological peptone (Oxoid), $20 \mathrm{~g}$ bacteriological agar (Oxoid) and $40 \mathrm{~g}$ D-glucose (dextrose; anhydrous) were suspended in $1000 \mathrm{ml}$ distilled water.

\section{H. Czapek Dox Agar Medium}

48 g Czapek-Dox agar powder (VWR) was suspended in $1000 \mathrm{ml}$ distilled water.

\section{Identification of Fungi}

Several isolated fungi were identified only to genus and others to species on the basis of micromorphological characteristics using suitable media, slide cultures (obtained by inoculating microfungi directly on a small square of agar medium) and identifications under a microscope.

\section{J. Statistical Analysis}

Results were processed and analyzed using SPSS statistical analysis package for Windows. Data is reported as mean \pm standard error of the mean (SEM) unless otherwise stated. A p-value of $<0.05$ was considered significant. Two-way analysis of variance was performed (ANOVA) on the pairs of variables likely to exhibit correlation.

\section{Results AND Discussion}

Some physicochemical characteristics of soils Irrigation by treated wastewater of factories, houses and streets (Misurata- Libya) have indicated a strong influence by this kind of water that have settled in the soil. It can be concluded that the effect of treated wastewater on soil metals content, water content and $\mathrm{pH}$ of soil depended not only on the period of Irrigation time to this water, but also the source of this kind of water. Results of soil analysis are shown in Table I, Fig. 1 and Fig. 2. PH values of the soil samples revealed no significant differences at all localities, although it ranged from 7.7 to 8.0 and showed no appreciable differences within localities. The differences between $\mathrm{pH}$ values may attributed to the differences of water physicochemical which affects gases and organisms activities, due to the reduction in $\mathrm{Co}_{2}$ while Photosynthesis and Respiration [13].

TABLE I: TOTAL SOLUBLE SALTS IN SOIL IRRIGATION BY WASTWATER. Sites A, B, C, (IRRIGATION AREA) AND D UN IRRIGATION AREA

\begin{tabular}{|c|c|}
\hline Locations & Total soluble salts $(\mathrm{ppm})$ \\
\hline A & 279.3 \\
\hline B & 272.6 \\
\hline C & 300.0 \\
\hline D & 241.6 \\
\hline
\end{tabular}

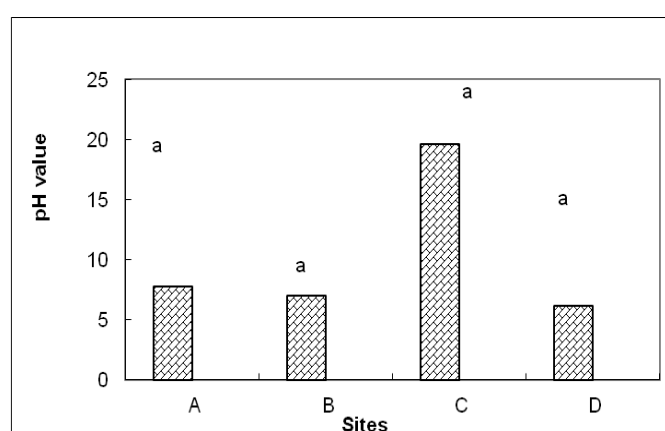

Fig. 1. PH in soil irrigation by wastwater. numbers with the same letter are not significantly different at $p=0.05$ according to duncan's test.

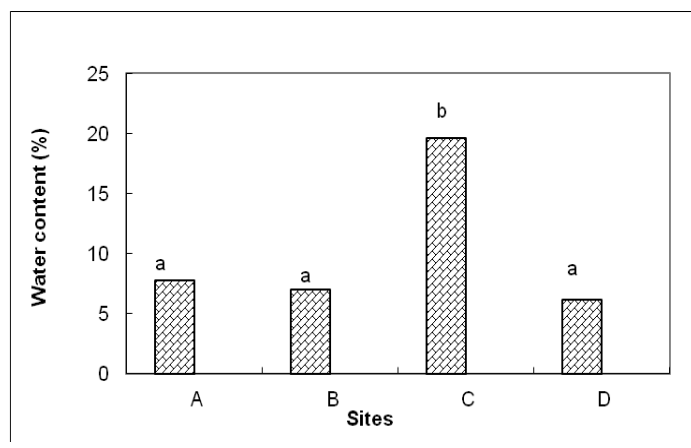

Fig. 2. Water content in soil irrigation by wastewater.

These finding is more than results absorbed before [14] but similar with previews result in the same area [7]. In this work the $\mathrm{pH}$ between 7.8 to 8.0. The soil with $\mathrm{pH}$ greater than 8.5 is generally called as sodic soil. But $\mathrm{pH}$ of all soils samples are less than 8.5 indicating that soil samples are free from sodicity hazards. This redaction could be due to the decreased amount of carbonate and bicarbonate [14]. The differences within localities may attribute to the changing of different wastewater sources [7]. Also water content ranged from 7.68 to 19.56 . \%. Since all samples contained relatively 
very low amounts of water content, this result is consistent with other finding of earlier studies on Libyan soils [4], [15]. The results showed that the amounts of total soluble salts in soil Irrigation by treated wastewater were more than in a control (un Irrigation area). This could be due to continues soil salty problem and low raining values [16]. Statistically there were significant differences in soil total soluble salts content between Irrigation location and un Irrigation samples $(P<0.001)$.

As shown in Table II, the concentrations of detected metals $(\mathrm{Cd}, \mathrm{Cu}, \mathrm{Pb}, \mathrm{Fe}$, and $\mathrm{Zn})$, showed variable values depending upon the sampling site. The increment of soil metals in the same area may be a result of precipitation of metals and other heavy metals over the years. These results are lower than results mentioned by [14]. No significant effect on the concentration of $\mathrm{Cu}$ in the soil when it had seven-year application of wastewater [17]. The iron and zinc concentration showed six times compared to the control. There were significant differences in some soil metals content $(\mathrm{Cd}, \mathrm{Fe}$ and $\mathrm{Zn})$ between first location and un Irrigation samples $(P<0.001)$. [18] shown that the application of wastewater with low $\mathrm{pH}$ causes a faster movement of the $\mathrm{Cd}$ and $\mathrm{Pb}$ to lower depths . Using wastewater irrigation for 16 years increased the concentration of $\mathrm{Zn}$ to toxic levels in the soil [19]. This work result's showed low Cd concentrations. Application of treated wastewater had no significant effect on the accumulation of soil Cd compared with the beginning stage and with the groundwater treatment [8].

TABLE II: Concentration (PpM) OF Metals (Cu, CD, PB, Zn,Fe) OF SoIl IRRIGATION BY WASTEWATER

\begin{tabular}{|c|c|c|c|c|c|}
\hline Site & $\mathrm{Cu}$ & $\mathrm{Cd}$ & $\mathrm{Pb}$ & $\mathrm{Zn}$ & $\mathrm{Fe}$ \\
\hline $\mathrm{A}$ & 0.033 & 0.002 & 0.006 & 0.017 & 1.23 \\
\hline $\mathrm{B}$ & 0.050 & 0.002 & 0.040 & 0.074 & 7.74 \\
\hline $\mathrm{C}$ & 0.089 & 0.022 & 0.080 & 0.067 & 2.55 \\
\hline $\mathrm{D}$ & 0.137 & 0.002 & 0.006 & 0.082 & 6.98 \\
\hline
\end{tabular}

The number of fungal colonies per gram of soil is shown in Table III and IV. Different soil localities support the growth of different fungal genera as shown in Table V, Fig. 3, Fig. 4, Fig. 5, Table IV, Fig. 6, Fig. 7, and Fig. 8. Four fungal genera namely Aspergillus, Rhizopus, Penicillium, and Fusarium were isolated in the present study. Such genera were previously reported in different Libyan soils polluted by like these metals such as dust from cement factory [20] and iron and still factory [21]. The increased microbial population at polluted sites by this kind of water may be attributed to different metals which may feed some of these microorganisms [4]. The absence of certain fungi in soils Irrigation by treated wastewater probably due to the relatively different metals concentrations high salts, $\mathrm{pH}$ and $\mathrm{pb}$, resulting from accumulation of some pollution metals [22]. Consequently, this may leads to low abundance or an absence of fungi in the soil [23], or can reduce microbial growth [24]. In the same way [25] reported that an increase in heavy metals in the environment affects qualitative and quantitative fungal composition. The effect of organic matter, total soluble salts, $\mathrm{pH}$ value, and metals on soil microbial flora are severally different from place to another.
Overall, heavy metals were generally toxic to soil microbial flora, and settled to soil and probably affected and change their physiochemical characteristics [26].

TABLE III: FUNGAL FLORA (COLONIES NUMBER) ISOLATED FROM DIFFERENT SOIL IRRIGATION BY WASTWATER. USING SABOURAUD

\begin{tabular}{|c|c|c|c|c|} 
MEDIUM. (-) NO GROWTH \\
\hline & $\mathrm{A}$ & $\mathrm{B}$ & $\mathrm{C}$ & $\mathrm{D}$ \\
\hline Rhizopus stolonifer & - & - & - & 2 \\
\hline Aspergillus $\mathrm{sp}_{1}$ & - & - & - & 1 \\
\hline Aspergillus. $\mathrm{sp}_{2}$ & - & - & - & 1 \\
\hline Aspergillus $\mathrm{sp}_{3}$ & 5 & 1 & 10 & 6 \\
\hline Penecillium $\mathrm{sp}_{1}$ & - & - & 7 & 1 \\
\hline Fusarium oxysporum & 16 & 18 & 14 & 15 \\
\hline
\end{tabular}

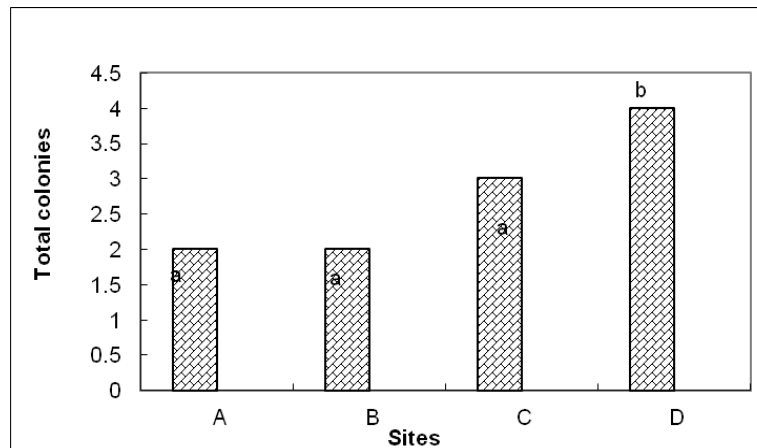

Fig. 3. Total fungal colonies isolated from soil irrigation by wastwater. using sabouraud medium.

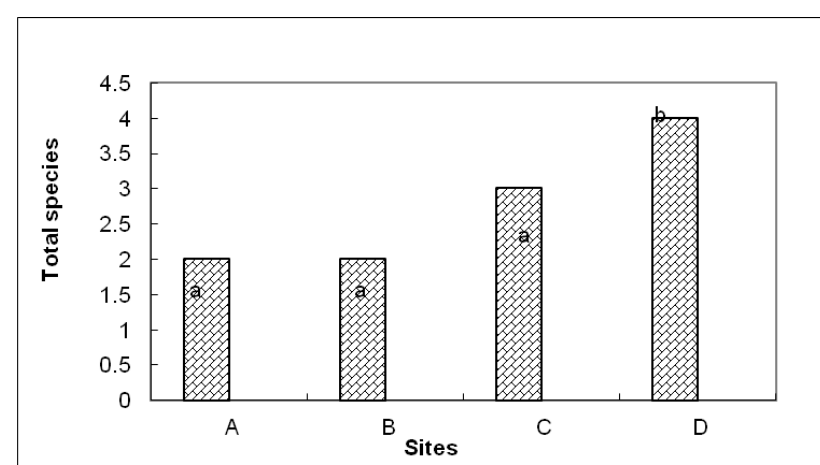

Fig. 4. total fungal species isolated from soil irrigation by wastwater. using sabouraud medium.

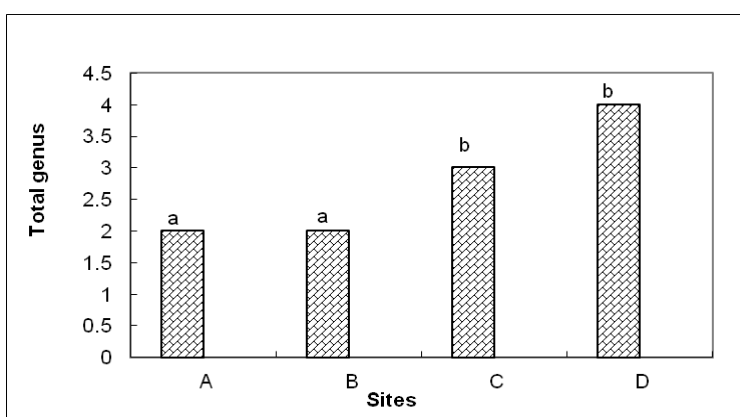

Fig. 5. Total fungal genus isolated from soil irrigation by wastwater. using sabouraud medium.

TABLE IV: FUNGAL FLORA (COLONIES NUMBER) ISOLATED FROM DiFFERENT SOIL IRRIGATION BY WASTWATER. USING CZAPEK MEDIUM (-)

\begin{tabular}{|c|c|c|c|c|}
\hline \multicolumn{5}{|c|}{ NO GROWTH } \\
\hline & $\mathrm{A}$ & $\mathrm{B}$ & $\mathrm{C}$ & $\mathrm{D}$ \\
\hline Fusarium oxysporum & 1 & 3 & 1 & - \\
\hline Fusarium $\mathrm{sp}$ & - & 5 & - & 2 \\
\hline Aspergillus $\mathrm{sp}_{1}$ & 1 & 1 & - & - \\
\hline Aspergillus $\mathrm{sp}_{2}$ & - & - & - & 4 \\
\hline Aspergillus flavus & & - & 1 & 5 \\
\hline Rhizopus stolonifre & 18 & 27 & 26 & 18 \\
\hline Penicillium chrysogenum. & 2 & 1 & 18 & 1 \\
\hline Penecillium $\mathrm{sp}_{1}$ & - & - & - & 1 \\
\hline
\end{tabular}




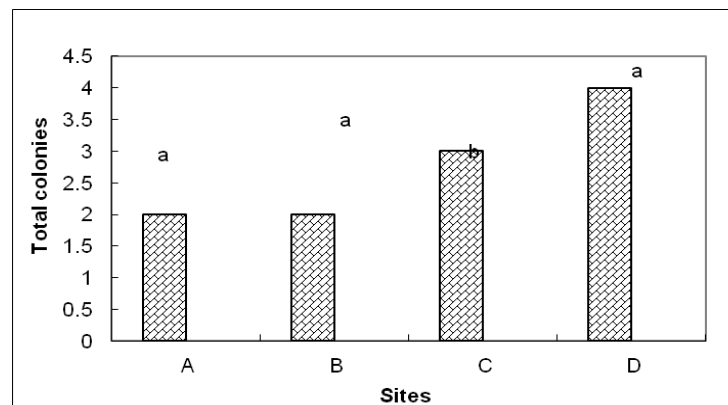

Fig. 6. Total fungal colonies isolated from soil irrigation by wastwater. Using czapek medium.

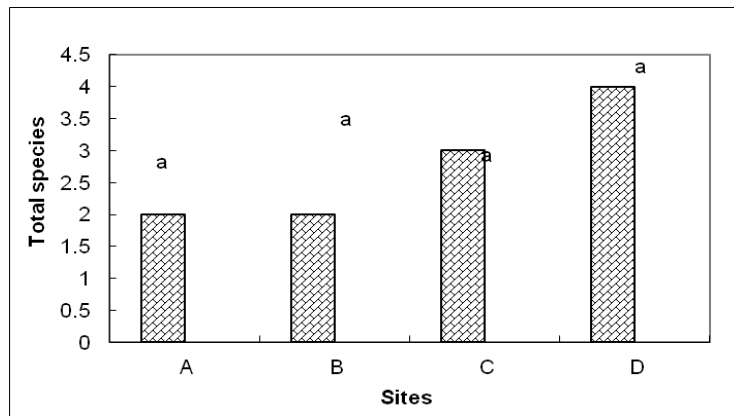

Fig. 7. Total fungal species isolated from soil irrigation by wastwater. Using czapek medium.

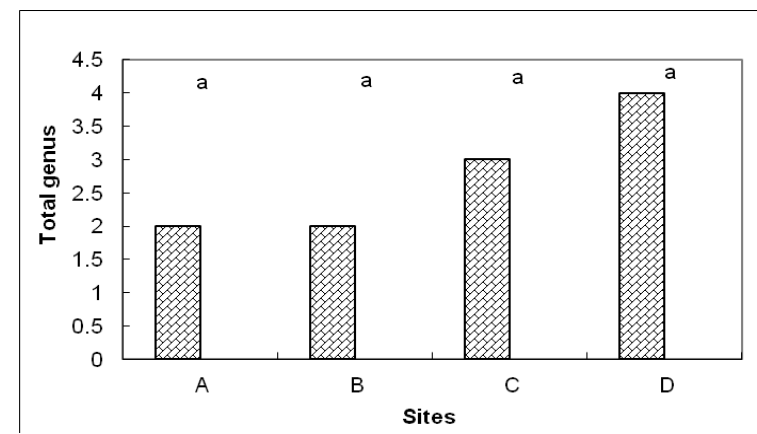

Fig. 8. Total fungal genus isolated from soil irrigation by wastwater. Using czapek medium.

\section{CONCLUSION}

The influence of wastewater in the area of Misurata on the presence of species was investigating by studying the numbers of colonies of various fungi. Conclusively, it has been observed that human activity has a negative influence on the quality of soil irrigated with wastewater in Misurata (city in Libya). The low fungal load, as well as high densities of total soluble salts and lead, suggests that pollution of soil by this kind of water has occurred. In addition, the quality of the water and $\mathrm{pH}$ values in the area studied, along with other observations, can be used to classify wastewater as the pollutant.

This work can conclude that the results obtained for the examined physiochemical characteristics of soil in the area studied prove that wastewater from the Misurata wastewater treatment station in Libya has had a significant impact on the soil. The affected soil properties are total soluble salts, metals content and microbial flora. These characteristics were found to be higher than those in similar soils from the same area. The increment of soil total soluble salts and lead in the same area may be a result of precipitation of wastewater over the years. Metal uptake from wastewater to plants and soil then affects organisms' bodies, a fact that seems to be reflected in this study.

This paper has indicated certain trends, but not enough variations in distance were investigated in the study area. Based upon the analysis of variance of the experimental data obtained, this paper concludes that the effect of wastewater on total soluble salts content, metals content of soil and microbial flora depended not only on period of irrigatetion to this kind of water, but also on the distances between sites.

In view of the sufferings of the Misurata wastewater treatment station area and other locations in Libya, especially in terms of plants, soil, air, and populations, agricultural land and water resources are considered one of several environmental challenges which Libya will have to face in the future. Better observation of air, soil and water pollution in polluted areas should take place through more research of this kind. Moreover, a great deal of attention should be paid by governmental establishments so that this type of pollution is decreased or discontinued altogether. This is especially important because the industrial and houses activity that leads to such pollution is likely to increase in the future as a result of rapid industrial growth. Extra soil physico-chemical characteristics must be taken into account to fully understand the effect of wastewater on soil bioavailability, mobility, and consequently the affect on microbial activities.

So far, the results throw some light on the intensity of the effect of a particular water on the soil properties. This work can conclude that in an area of Misurata wastewater treatment station in Libya, several fungi can not grow in soil. The questions are, do fungi have similar growth patterns in media to those in the field? What concentrations of metals or salts can these fungi tolerant? Several experiments undertaken to address these questions directly by studying the ability of the fungi to grow in laboratory conditions in the presence of a variety of salts and metals concentrations.

\section{ACKNOWLEDGEMENT}

Authors are thankful to Misurata wastewater treatment station and iron and still factory for providing necessary facilities for analysis done in this work.

\section{REFERENCES}

[1] E. Y. Oyinlola and I. A. Aliyu, "Effect of town waste and fertilizer on growth and heavy metal concentration of tomato plant," Chem. Class Journal, vol. 2, pp. 32-35, 2005.

[2] K. Dilip, Introductory Soil Science, 2nd ed. Kalyani Publishers, 2006.

[3] T. Streck and J. Richter, "Heavy metal displacement in a sandy soil at the field scale: I. Measurements and parameterization of sorption," J. Environ. Qual., vol. 26, pp. 49-56, 1997.

[4] A. Mlitan and E. Hack. "Effects of some cement constituents on growth of Aspergillus nidulans," presented at the 163rd SGM Trinity College Dublin Meeting, 8-11 September, 2008.

[5] T. Noriko, H. Shighisa, and S. Yoshio, "Seasonal changes in species composition and production of periphyton in an urban river running through a $\mathrm{Pb}$ and copper mining region," Japan. J. Limnol., vol. 51, pp. 225-235, 1990.

[6] D. G. Woodfine, M. Havas, and J. Acreman, "Nickel and copper tolerance of phytoplankton isolated from a recovering lake near Sudbury, Canada. Geochemistry," Exploration, Environ. Anal., vol. 2, no. 2, pp. 203-207, 2003.

[7] M. M. Alshroshi, "The effect of wastewater on vegetables in different areas in Misurata city," Msc Thesis, Nasher University, Misurata, Libya, pp. 13, 1999.

[8] J. Abedi-Koupai, B. Mostafazadeh-Fard, M. Afyuni, and M. R. Bagheri "Effect of treated wastewater on soil chemical and physical properties in an arid region," Plant Soil Environ., vol. 52, no. 8, pp. 335-344. 2006. 
[9] P. Najafi and S. Nasr, "Comparison effects of wastewater on soil chemical properties in three irrigation methods," Journal Research on Crops., vol. 10, no. 2, pp. 277-280, 2009.

[10] AOAC, Methods of Analysis, 14th ed. Washington D.C., 1984.

[11] R. K. Chaturvedi and K. Sanka, Laboratory Manual for the Physico-Chemical Analysis of Soil, Water and Plant, Wildlife Institute of India, Dehradun, 2006.

[12] H. Biyik, A. Imali, E. Atalan, S. Tufenkci, and E. Ogun. "Diversity of microfungi in soil polluted by cement factory," Fresenius Environmental Bulletin, vol. 14, pp. 130-137, 2005.

[13] A. A. Alyasery, "Study of phisichemical of different areas in Sok Asheuak and Alhbayesh in De gar," De gar Gournal, vol. 3, no. 3, pp. 103-107. 2007.

[14] D. V. Sonawane, S. P. Lawande, V. B. Gaikwad, and S. R. Kuchekar. "Impact of industrial wastewater on soil quality and organic matter around kurkumbh Industrial area daund, pune district (MS)," Int. J. Chem. Sci., vol. 8, no. 1, pp. 97-102, 2010.

[15] F. M. Almhashi, "Some physical and ecological studies for soil fungi in Misurata-Libya," MSC Thesis, Nasser University, Misurata, Libya, p. $125,1999$.

[16] S. N. N. Al-Seedi and F. J. F. Al-Auboody, "Ecological study on some physical and chemical properties of Al-Gharaf river water in Thi - Qar governorate," Journal of College of Education, vol. 1, no. 4. pp. 44-50, 2011.

[17] M. S. M. Saber, "Prolong effect of land disposal of human waste on soil conditions," Water Sci. Technol., vol. 18, pp. 371-374. 1986

[18] D. J. Silver and L. E. Sommers, "Extractability of $\mathrm{Cu}, \mathrm{Zn}, \mathrm{Cd}$ and $\mathrm{Pb}$ in soils incubated with sewage sludge," J. Environ. Qual., vol. 6, pp. 47-52, 1977.

[19] R. Boll, H. Dernbach and R. Kayser, "Aspects of land disposal of wastewater as experienced in Germany," Water Sci. Technol., vol. 18 , pp. 383-390, 1986.

[20] A. Mlitan, A. Alajtal, and A. Alsadawy, "Toxicity of heavy metals and microbial analysis of soil samples collected from the area around Zliten cement factory," Open Journal of Air Pollution, vol. 2, no. 1, pp. 25-28. 2013.

[21] A. B. Mlitan, "Heavy metals and microbial toxicity of analysis of soil samples near Iron and Still Factory (Misurata, Libya)," in Proc. 2nd International Conference on Chemical, Environmental and Biological Sciences, Dubai, UAE, March 17-18, 2013.

[22] D. A. Ade-Ademilua and O. E. Obalola, "The effect of cement dust pollution on Celosia Argentea Lagos Spinach plant," Journal of Environment Science and Technology, vol. 1, pp. 47-55, 2008.
[23] O. A. Al-Khashman and R. A. Shawabkeh, "Metals distribution in soils around the cement factory in southern Jordan," Environmental Pollution, vol. 140, pp. 387-394. 2006.

[24] M. M. Bagy, "Saprophytic and keratinophilic fungi isolated from desert and cultivated soils continuously exposed to cement dust particles in Egypt. Zentralbl," Mikrobiolo. vol. 147, pp. 418-426, 1992.

[25] G. M. Gadd, "Interactions of fungi with toxic metals," New Phytologist, vol. 124 , pp. 25-60, 1993.

[26] A. M. J. Almamoori, F. M. Hassan, and T. I. Kassim, "Impact of industrial waste water on the properties of one major drainage in the region of the middle Euphrates /Iraq," Int. J. Chem. Sci., vol. 10, no. 4, pp. 1785-1798, 2012.

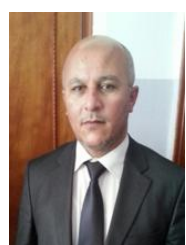

Abdulmajeed Bashir Mlitan is an assistant professor specializing in environmental microbiology with an emphasis on soil, air and environmental pollution. His research focuses on introduce many pollution negative points. He was born in Misurata, Libya in 1973. He got the $\mathrm{Ph}$.D. degree in environmental microbiology in 2010 from Newcastle university in U.K. His Ph.D. dissertation is focusing on industrial cement dust pollution on fungi activities. He got the M.Sc. degree in environmental pollution in 2000 from Misurata University, Libya. He got the B.Sc. degree in biology in 1995 from Altahadi University, Misurat, Libya. He works as an assistant professor in Misurata University, Libya from 2013 to present. He is the head of Botany Department to present, Misurat University, Misurata Libya. He has over 10 international journal/conference publications.

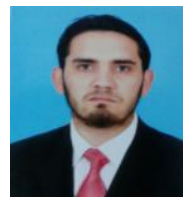

Abdallah Abufalgha is a M.Sc. student in Botany Department, Misurat University, Misurata Libya. He was born in Misurata, Libya in 1988. He got the B.Sc. degree in biology in 2012 from Misurata University, Misurat, Libya. He is interest in environment pollution area.

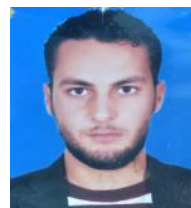

Abdelaziz Swalem is a M.Sc. student in Botany Department, Misurat University, Misurata Libya. He was born in Misurata, Libya in 1986. He got the B.Sc. degree in biology in 2012 from Misurata University, Misurat, Libya. He is interest in environment pollution area. 